\title{
Investigation of INDEL variants in apoptosis: the relevance to gastric cancer
}

\author{
Giovanna Chaves Cavalcante ${ }^{1}$, Milene Raiol de Moraes ${ }^{1}$, Cristina Maria Duarte Valente ${ }^{1}$, Caio Santos Silva ${ }^{1}$, \\ Antônio André Conde Modesto², Paula Baraúna de Assumpção², Paulo Pimentel de Assumpção², \\ Sidney Santos ${ }^{1,2}$ and Ândrea Ribeiro-dos-Santos ${ }^{1,2^{*}}$ (D
}

\begin{abstract}
Background: Apoptosis is a type of cell death involved in different pathways inherent to the cell and the evasion from this mechanism has been related to cancer, although this process remains not very well comprehended. Gastric cancer (GC) is one of the most incident and aggressive types of cancer worldwide. In this study, we analyzed the distribution of INDEL variants in GC patients (Case) and individuals from the general population (Control) from the Amazon region, in which GC is remarkably frequent.

Methods: A panel of nine INDEL markers in apoptosis-related genes (BCL2 rs11269260, CASP3 rs4647655, CASP8 rs3834129 and rs59308963, CASP9 rs4645982 and rs61079693, FADD rs4197, FAS rs10562972 and TP53 rs17880560) was developed and genotyped by multiplex PCR in both groups.

Results: In our analyses, only marker rs4197 (FADD gene) was associated to GC development as follows: INS/DEL genotype of rs4197 increasing in about 2-fold the chances of developing this type of cancer $(P=0.046 ; O R=1.940$; $95 \% \mathrm{Cl}=1.011-3.725)$.

Conclusion: Our results suggest that rs4197 (FADD gene) might play a role in gastric carcinogenesis in the investigated population. More studies are needed to clarify this relation. Here, we highlight the importance of investigating INDEL variants in genes involved in apoptosis.
\end{abstract}

Keywords: Gastric Cancer, Apoptosis, INDEL, FADD

\section{Background}

Apoptosis is a type of programmed cell death (PCD) that may occur as a response to intra- or extracellular stimuli, leading to intrinsic pathway or extrinsic pathway, respectively. These are independent pathways that converge to the executor phase, the final stage of this death process $[1-3]$. Several genes are involved in apoptosis, out of which we highlight: BCL2, CASP9 in the

\footnotetext{
* Correspondence: akelyufpa@gmail.com

'Laboratório de Genética Humana e Médica, Programa de Pós-Graduação em Genética e Biologia Molecular, Universidade Federal do Pará, Av. Augusto Correa 01, Belém, Pará 66075-110, Brazil

${ }^{2}$ Núcleo de Pesquisas em Oncologia, Programa de Pós-Graduação em Oncologia e Ciências Médicas, Universidade Federal do Pará, Belém, Pará 66073-005, Brazil
}

intrinsic pathway; $F A S, F A D D, C A S P 8$ in the extrinsic pathway; TP53 in both pathways; and CASP3 in the executor phase. All of these genes are important to the apoptotic mechanism, so that variants affecting their functions might dysregulate cell homeostasis and contribute to tumor development [4]. Although the apoptosis process is still not completely comprehended, this type of cell death mechanism has been related to cancer.

Gastric cancer (GC) is one of the most frequent and aggressive types of cancer worldwide, usually presenting an unfavorable prognosis $[5,6]$. In Brazil, GC is the sixth most incident and the fifth most mortal type of cancer [6]. Brazil is a country with a highly admixed population, composed mainly of European, African, Amerindian and

(c) The Author(s). 2020 Open Access This article is licensed under a Creative Commons Attribution 4.0 International License, which permits use, sharing, adaptation, distribution and reproduction in any medium or format, as long as you give appropriate credit to the original author(s) and the source, provide a link to the Creative Commons licence, and indicate if changes were made. The images or other third party material in this article are included in the article's Creative Commons licence, unless indicated otherwise in a credit line to the material. If material is not included in the article's Creative Commons licence and your intended use is not permitted by statutory regulation or exceeds the permitted use, you will need to obtain permission directly from the copyright holder. To view a copy of this licence, visit http://creativecommons.org/licenses/by/4.0/ The Creative Commons Public Domain Dedication waiver (http://creativecommons.org/publicdomain/zero/1.0/) applies to the data made available in this article, unless otherwise stated in a credit line to the data. 
Asian ancestry. Many studies in this country have highlighted differences between these ancestries and the Brazilian regions [7-11], including aspects of cancer development [12]. This is also notable by the higher incidence of GC in northern Brazil in comparison to the general rates of this country and the world [13].

Therefore, in this study, we aimed to analyze the distribution of nine Insertion/Deletion (INDEL) polymorphisms in apoptosis-related genes in gastric cancer patients and cancer-free individuals from the general population of the Amazon region.

\section{Methods}

\section{Sampling}

Case group was composed of 93 individuals with gastric cancer diagnosis from Pará state and control group was composed of 98 cancer-free individuals of the general population from the same state, located in the Amazon region of Brazil. From each individual, blood or buccal swab samples were collected. All participants signed an informed consent, with approval by the Committee for Research Ethics of Hospital João de Barros Barreto under Protocol Number: 64399617.7.0000.5634.

\section{DNA extraction and quantification}

DNA extraction was performed with phenol-chloroform method, based on [14]. Quantification of DNA was performed with NanoDrop 1000 and Qubit ${ }^{\text {tM }}$ (Thermo Fisher Scientific, Wilmington, DE, USA).

\section{Selection of INDEL markers}

The markers were selected according to the main criteria: (i) they must be in genes involved in apoptosis pathways; (ii) they must be INDEL-type polymorphisms, hence presenting the potential to modify the function of the protein; (iii) they must have minor allele frequency $(\mathrm{MAF}) \geq 10 \%$. Table 1 shows the technical features of the investigated markers.

\section{Genotyping}

The panel of markers described above was genotyped by Multiplex PCR, allowing the amplification of all of these markers in a single reaction, followed by capillary electrophoresis and fragment analysis. Protocol preparation of PCR samples was: $5.0 \mu \mathrm{L}$ of QIAGEN Multiplex PCR Master Mix, $1.0 \mu \mathrm{L}$ of Q-solution, $2.0 \mu \mathrm{L}$ of water, $1.0 \mu \mathrm{L}$ of primer mix and $1.0 \mu \mathrm{L}$ of DNA per sample. Amplification reaction was done using Veriti thermal cycler (Thermo Fisher Scientific) with the following protocol: $95^{\circ} \mathrm{C}$ for $15 \mathrm{~min}$, followed by 35 cycles of $94^{\circ} \mathrm{C}$ for $45 \mathrm{~s}$, $60^{\circ} \mathrm{C}$ for $90 \mathrm{~s}$ and $72{ }^{\circ} \mathrm{C}$ for $1 \mathrm{~min}$, with a final extension at $70^{\circ} \mathrm{C}$ for $30 \mathrm{~min}$. The protocol for capillary electrophoresis was: $1.0 \mu \mathrm{L}$ of PCR product, $8.5 \mu \mathrm{L}$ of HI-DI deionized formamide and $0.5 \mu \mathrm{L}$ of GeneScan $500 \mathrm{LIZ}$ pattern size standard (reagents by Thermo Fisher Scientific). DNA fragments were separated and analyzed using ABI PRISM 3130 genetic analyzer and GeneMapper ID v.3.2 software (both by Thermo Fisher Scientific).

In addition to the panel of apoptosis markers, a panel of 61 ancestry informative markers (AIM) previously developed and expanded by our research group was also employed in this study, following the established protocols $[15,16]$. This was done considering that the Brazilian population is highly admixed in terms of genetic contributions from different parental populations, mainly European, African and Native American. In order

Table 1 Technical characterization of the markers included in the panel

\begin{tabular}{|c|c|c|c|c|c|c|}
\hline Gene & ID & Region & Alleles & MAF & Primers & Amplicon \\
\hline$\overline{B C L 2}$ & rs11269260 & Intron & TCTATCACCGATCATT/- & 0.37 & $\begin{array}{l}\text { F5'GCTTCCAGTTCCATCCATGT3' } \\
\text { R5'CTCAGCGTGGTAGTGTTGGA3' }\end{array}$ & $189-205$ \\
\hline CASP3 & rs4647655 & Intron & -/AAATCCTGAA & 0.28 & $\begin{array}{l}\text { F5'AGGAGTATCCCCTCGTGGAC3' } \\
\text { R5'CAAGAGTCAGGCAAAAACAGG3' }\end{array}$ & 379-389 \\
\hline CASP8 & rs3834129 & Promoter & AGTAAG/- & 0.39 & $\begin{array}{l}\text { F5'CTCTTCAATGCTTCCTTGAGGT3' } \\
\text { R5'CTGCATGCCAGGAGCTAAGTAT3' }\end{array}$ & $249-255$ \\
\hline CASP8 & rs59308963 & Intron & ATTCTGTC/- & 0.26 & $\begin{array}{l}\text { F5'TाTाTGTCCTCCAAGCTTCC3' } \\
\text { R5'GAACAAGAGAGAGGGCAGGA3' }\end{array}$ & $261-269$ \\
\hline CASP9 & rs4645982 & Intron & -/TCCCCGCACTGACCTCACG & 0.42 & $\begin{array}{l}\text { F5'GGTGACCCCAGAATTGACCCT3' } \\
\text { R5'GCCCTCAGGACGCACCTCTG3' }\end{array}$ & $336-353$ \\
\hline CASP9 & rs61079693 & Intron & AAAA/- & 0.32 & $\begin{array}{l}\text { F5'CATGCACAGCTATCCAGGAG3' } \\
\text { R5'TGTTCCTGTCCGATAGATGC3' }\end{array}$ & $458-462$ \\
\hline FADD & rs4197 & 3' UTR & $-/ T G T$ & 0.47 & $\begin{array}{l}\text { F5'TGCCCCTACTTAGCAGTCTCA3' } \\
\text { R5'GAGAGGTGGAGAACTGGGATT3' }\end{array}$ & $278-281$ \\
\hline FAS & rs10562972 & Intron & $\Pi \mathrm{TC} /-$ & 0.12 & $\begin{array}{l}\text { F5'GCATCAGGACGCTGAACATA3' } \\
\text { R5'AATGCAACTTGCTCCAGAGG3' }\end{array}$ & $368-371$ \\
\hline TP53 & rs17880560 & 3'-Flanking & -/GCCGTG & 0.21 & $\begin{array}{l}\text { F5'CTGTGTGTCTGAGGGGTGAA3' } \\
\text { R5'ATCCTGCCACTITCTGATGG3' }\end{array}$ & $400-406$ \\
\hline
\end{tabular}


to control the possible influence of these ancestries in the genotypic distribution, leading to misinterpretation, we have used this AIM panel, composed of ancestryspecific markers that are able to estimate individual and population genetic contribution.

\section{Statistical analysis}

Inference of genetic ancestry based on the AIM panel was done with Structure software v.2.3.4 [17]. R language [18] was used to assess Hardy-Weinberg Equilibrium (HWE) of genotype distribution. JASP software v. 0.9.2.0 [19] was used to perform all other statistical analyses (Student's $t$ test, chi-squared test, logistic regression). $P$-values $\leq 0.05$ were considered statistically significant.

\section{Results}

Firstly, we assessed HWE for genotypic distribution and found that only two markers, rs4645982 (CASP9) and rs4197 $(F A D D)$, deviated from HWE in case group $(P=$ 0.0035 and $P=0.0026$, respectively).

Then, we compared sex, age and controlled genetic ancestry of case and control groups in order to verify possible confounding factors. In addition, staging (I-IV) of patients was assessed. These data are described in Table 2.

In these analyses, only age presented a statistically significant difference and it was included for correction in the panel analysis. It is noteworthy that $53 \%$ of the patients included in case group presented diffuse-type adenocarcinoma, while $47 \%$ presented intestinal-type adenocarcinoma, and the observed mean age (mean age \pm SE) for these subtypes was $39.20 \pm 1.397$ and $44.34 \pm 1.526$, respectively, so that the mean age for case group as a whole was lower than it is usually observed for patients with GC in the world.

Table 2 Demographic data for case (gastric cancer patients) and control groups

\begin{tabular}{|c|c|c|c|}
\hline Variable & Case & Control & $P$-value \\
\hline $\mathrm{N}$ & 91 & 95 & \\
\hline Age, years ${ }^{a}$ & $42.15 \pm 1.66$ & $32.18 \pm 1.17$ & $<0.001$ \\
\hline Sex, $\%$ of male/female & $48.9 / 51.1$ & $50.0 / 50.0$ & 1.000 \\
\hline European ancestry ${ }^{c}$ & $0.541 \pm 0.028$ & $0.587 \pm 0.021$ & 0.251 \\
\hline African ancestry ${ }^{c}$ & $0.152 \pm 0.018$ & $0.124 \pm 0.013$ & 0.966 \\
\hline Native American ancestry ${ }^{c}$ & $0.307 \pm 0.022$ & $0.289 \pm 0.019$ & 0.649 \\
\hline Stage I, \% & 3.3 & NA & 0.241 \\
\hline Stage $\|, \%$ & 20.7 & NA & \\
\hline Stage III, \% & 26.0 & NA & \\
\hline Stage IV, \% & 50.0 & NA & \\
\hline
\end{tabular}

${ }^{a}$ Values are expressed as mean \pm SE (Standard Error of Mean), Student's t-test; b 'Values are expressed as distribution percentages, chi-squared test; ${ }^{C}$ Values are expressed as mean $\pm \mathrm{SE}$, Mann-Whitney test. NA Not Applicable
Nevertheless, in the analysis performed for each genotype (carriers of a genotype vs. non-carriers of such genotype as a reference group), only INS/DEL genotype of rs4197 $(P=0.046 ;$ OR $=1.940 ; 95 \% \mathrm{CI}=1.011-3.725)$ presented significant association to risk of developing $\mathrm{GC}$ in the investigated population (Table 3).

\section{Discussion}

In the last decade, it has been established that tumors display different abilities in order to grow, survive and proliferate, of which we highlight here resistance to cell death, including apoptosis [20]. However, there is still a lot to discover about these mechanisms.

Apoptosis is a complex process that involves the protein action of several different genes, such as BCL2, CASP3, CASP8, CASP9, FADD, FAS and TP53. Dysfunction in these genes may lead to deregulation of cell death and, thus, tumor development. Therefore, in this study, we investigated whether nine INDEL variants in the mentioned genes might influence gastric carcinogenesis, by comparing their distribution in GC patients and cancer-free individuals.

Regarding the observed deviation from HWE in the distribution of rs4197 and rs4645982 in case group, no previous studies were found with these markers, but their genotype distribution varies greatly between different populations in 1000 Genomes Project database [21]. Curiously, their distribution also presented a deviation from HWE in most populations in that database, suggesting that there could be a selective advantage leading to this pattern and/or that the deviation observed here could be due to population substructure, especially considering the relatively recent admixture process in Brazil, as previously observed for other markers in this population [7, 22]. As such, it is an expected process in admixed populations, and it could even highlight the potential of these markers. In fact, it has been suggested that HWE deviation only in patient's group could support possible locus-disease associations [23].

Then, we carried on to the analyses performed for each genotype (carriers of a genotype vs. non-carriers of such genotype as a reference group) in cases and controls. In these analyses, our results suggest that individuals carrying INS/DEL of rs4197 have about 2-fold chances of developing GC than non-carriers $(P=0.046$; $\mathrm{OR}=1.940 ; 95 \% \mathrm{CI}=1.011-3.725$ ).

To the best of our knowledge, this is the first study investigating variant rs4197. It is a 3-bp INDEL in the 3' UTR of FADD gene, a key adaptor molecule that transmits death signals from death receptors during extrinsic apoptosis, thus being crucial to a variety of processes [24]. In fact, it seems that it could affect protein features due to the importance of 3'-UTR [25]. Depletion of FADD protein action may lead to failure of apoptosis and, thus, to tumor development. Absence of FADD 
Table 3 Genotypic distribution of the investigated variants for patients with GC in comparison to control group. P-value, OR and 95\% Cl were obtained with logistic regression adjusted for age, which was done for the genotype as reference in each line (DEL/DEL vs. the other genotypes of that marker, and the same for INS/DEL and INS/INS)

\begin{tabular}{|c|c|c|c|c|c|}
\hline Gene & Genotype & Case $(\%)^{*}$ & Control (\%)* & $P$-value & OR $(95 \% \mathrm{Cl})$ \\
\hline \multirow[t]{4}{*}{$B C L 2$} & rs11269260 & 93 & 98 & & \\
\hline & DEL/DEL & $13(14)$ & $19(19.4)$ & 0.844 & $1.090(0.463-2.567)$ \\
\hline & INS/DEL & $51(54.8)$ & $42(42.9)$ & 0.149 & $1.589(0.848-2.977)$ \\
\hline & INS/INS & $29(31.2)$ & $37(37.8)$ & 0.092 & $0.556(0.281-1.101)$ \\
\hline \multirow[t]{4}{*}{ CASP3 } & rs4647655 & 93 & 96 & & \\
\hline & DEL/DEL & $47(50.5)$ & $48(50.0)$ & 0.898 & $0.959(0.511-1.802)$ \\
\hline & INS/DEL & 39 (41.9) & 39 (40.6) & 0.995 & $1.002(0.528-1.904)$ \\
\hline & INS/INS & $7(7.5)$ & $9(9.4)$ & 0.825 & $1.136(0.365-3.537)$ \\
\hline \multirow[t]{8}{*}{ CASP8 } & rs3834129 & 93 & 98 & & \\
\hline & DEL/DEL & $27(29.0)$ & $19(19.4)$ & 0.098 & $1.851(0.893-3.835)$ \\
\hline & INS/DEL & $38(40.9)$ & $42(42.9)$ & 0.987 & $0.995(0.526-1.880)$ \\
\hline & INS/INS & $28(30.1)$ & $37(37.7)$ & 0.132 & $0.596(0.303-1.169)$ \\
\hline & rs59308963 & 89 & 93 & & \\
\hline & DEL/DEL & $30(33.7)$ & $29(31.2)$ & 0.749 & $1.116(0.568-2.195)$ \\
\hline & INS/DEL & $41(46.1)$ & $44(47.3)$ & 0.727 & $0.893(0.471-1.690)$ \\
\hline & INS/INS & $18(20.2)$ & $20(21.5)$ & 0.953 & $1.024(0.467-2.244)$ \\
\hline \multirow[t]{8}{*}{ CASP9 } & rs4645982 & 81 & 58 & & \\
\hline & DEL/DEL & 16 (19.8) & $13(22.4)$ & 0.897 & $0.943(0.392-2.272)$ \\
\hline & INS/DEL & $24(29.6)$ & $20(34.5)$ & 0.583 & $0.808(0.377-1.732)$ \\
\hline & INS/INS & $41(50.6)$ & $25(43.1)$ & 0.535 & $1.254(0.613-2.567)$ \\
\hline & rs61079693 & 89 & 94 & & \\
\hline & DEL/DEL & $22(24.7)$ & $26(27.7)$ & 0.418 & $0.742(0.360-1.529)$ \\
\hline & INS/DEL & $46(51.7)$ & $44(46.8)$ & 0.765 & $1.102(0.585-2.076)$ \\
\hline & INS/INS & $21(23.6)$ & $24(25.5)$ & 0.621 & $1.209(0.570-2.563)$ \\
\hline \multirow[t]{4}{*}{ FADD } & rs4197 & 93 & 97 & & \\
\hline & DEL/DEL & $31(33.3)$ & $41(42.3)$ & 0.099 & $0.573(0.295-1.111)$ \\
\hline & INS/DEL & $57(61.3)$ & $48(49.5)$ & 0.046 & $1.940(1.011-3.725)$ \\
\hline & INS/INS & $5(5.4)$ & $8(8.2)$ & 0.441 & $0.600(0.163-2.202)$ \\
\hline \multirow[t]{4}{*}{ FAS } & rs10562972 & 89 & 93 & & \\
\hline & DEL/DEL & $1(1.1)$ & $0(0.0)$ & 0.988 & $991,452.554(0.000-\infty)$ \\
\hline & INS/DEL & $10(11.2)$ & $21(22.6)$ & 0.260 & $0.603(0.250-1.454)$ \\
\hline & INS/INS & 78 (87.6) & $72(77.4)$ & 0.329 & 1.535 (0.650-1.125) \\
\hline \multirow[t]{4}{*}{ TP53 } & rs17880560 & 87 & 93 & & \\
\hline & DEL/DEL & $57(65.5)$ & $58(62.4)$ & 0.738 & $1.119(0.579-2.166)$ \\
\hline & INS/DEL & $26(29.9)$ & $31(33.3)$ & 0.714 & $0.880(0.445-1.741)$ \\
\hline & INS/INS & $4(4.6)$ & $4(4.3)$ & 0.964 & $1.035(0.232-4.623)$ \\
\hline
\end{tabular}

*Sample number; $P$-value: $P$-value adjusted for age, OR Odds Ratio, $C l$ Confidence Interval

expression has been suggested as marker of tumor development in mice and cancer prognosis in humans, due to the involvement of this protein with cell apoptosis, survival and proliferation [26]. Therefore, investigation of $F A D D$ gene should help the understanding of cancer development, including gastric carcinogenesis.
As for the variants that did not present a statistical association here, this may suggest that they either do not play a role in gastric carcinogenesis or it is a populationspecific treat. Indeed, some of these variants have been associated cancer development in a few studies, but not in others. For instance, one of these variants (rs3834129 
in CASP8) has been previously studied by our research group in other sampling of the same region: we have associated INS/INS genotype of this variant to reduced chances of developing B-cell acute lymphoblastic leukemia [27], but have not found any association of this variant with GC or colorectal cancer [22], so that our study corroborates the findings in the latter. Thus, the association of such variants to GC and other types of cancer is still a matter of great discussion.

\section{Conclusions}

Despite a few limitations (sample number and average age of both groups), this study contributed to an increased knowledge on variants in apoptosis-related genes in regard to GC development. As future perspectives, we recommend studies in the same population with a greater sample number and in different populations for comparison, as well as functional studies focused on the proteins to possibly reinforce the involvement of $F A D D$ gene in gastric carcinogenesis. Although such future studies are recommended to strengthen our results, this work contributes to a better understanding of these genes and INDEL variants in regard to gastric cancer.

\footnotetext{
Abbreviations

AIM: Ancestry Informative Marker; $B C L 2: B C L 2$ apoptosis regulator; CASP3: Caspase 3; CASP8: Caspase 8; CASP9: Caspase 9; Cl: Confidence Interval; DEL: Deletion; DNA: Deoxyribonucleic Acid; FADD: Fas associated via death domain; FAS: Fas cell surface death receptor; GC: Gastric Cancer; HWE: Hardy-Weinberg Equilibrium; ID: Identification; INDEL: Insertion/ Deletion; INS: Insertion; MAF: Minor Allele Frequency; OR: Odds Ratio; PCD: Programmed Cell Death; PCR: Polymerase chain reaction; TP53: Tumor protein p53; UTR: Untranslated Region
}

\section{Acknowledgements}

We thank Dr. André M. Ribeiro-dos-Santos for great technical assistance.

\section{Authors' contributions}

GCC designed the study, performed part of the experiments, performed data analysis and wrote the manuscript; MRM, CMDV, CSS and AACM performed part of the experiments; PBA and PPA participated in the acquisition of data and gave contributions to the manuscript; SS gave major contributions to the study design and to the manuscript; ARS designed and coordinated the study and gave major contributions to the manuscript. The author(s) read and approved the final manuscript.

\section{Funding}

This research was funded by Conselho Nacional de Desenvolvimento Científico e Tecnológico (CNPq), Coordenação de Aperfeiçoamento de Pessoal de Nível Superior (CAPES/Brazil), Fundação Amazônia de Amparo a Estudos e Pesquisas (FAPESPA), Pró-Reitoria de Pesquisa e Pós-Graduação (PROPESP/UFPA) and Fundação de Amparo e Desenvolvimento da Pesquisa (FADESP/UFPA). This work is part of Rede de Pesquisa em Genômica Populacional Humana (Biocomputacional - Protocol no. 3381/2013/CAPES). The funders had no role in any of the following: design of the study; collection, analyses, or interpretation of data; writing of the manuscript; decision to publish the results.

\section{Availability of data and materials}

The datasets generated and/or analyzed during the current study are available in the Figshare repository (https://doi.org/10.6084/m9.figshare. 13040078).
Ethics approval and consent to participate

All participants signed an informed consent, with approval by the Committee for Research Ethics of Hospital João de Barros Barreto under Protocol Number: 64399617.7.0000.5634.

\section{Consent for publication}

Not applicable.

\section{Competing interests}

The authors declare no competing interests.

Received: 27 February 2020 Accepted: 4 October 2020

Published online: 19 October 2020

References

1. Elmore S. Apoptosis: a review of programmed cell death. Toxicol Pathol. 2007;35(4):495-516.

2. Galluzzi L, Vitale I, Aaronson SA, Abrams JM, Adam D, Agostinis P, et al. Molecular mechanisms of cell death: recommendations of the nomenclature committee on cell death 2018. Cell Death Differ. 2018;25(3): 486-541.

3. Kerr JFR, Wyllie AH, Currie AR. Apoptosis: a basic biological phenomenon with Wideranging implications in tissue kinetics. Br J Cancer. 1972;26(4):23957.

4. Cavalcante GC, Schaan AP, Cabral GF, Santana-da-Silva MN, Pinto P, Vidal AF, et al. A Cell's fate: an overview of the molecular biology and genetics of apoptosis. Int J Mol Sci. 2019;20(17):4133.

5. Pinheiro D. Do R, Ferreira WAS, Barros MBL, Araújo MD, Rodrigues-Antunes $\mathrm{S}$, Borges $\mathrm{B}$ do $\mathrm{N}$. perspectives on new biomarkers in gastric cancer: diagnostic and prognostic applications. World J Gastroenterol. 2014;20(33): $11574-85$.

6. GLOBOCAN. Cancer today. 2018 [cited 2019 Mar 6]. Available from: http:// gco.iarc.fr/today/home.

7. Amador MAT, Cavalcante GC, Santos NPC, Gusmão L, Guerreiro JF, Ribeirodos-Santos $\hat{A}$, et al. Distribution of allelic and genotypic frequencies of IL1A, IL4, NFKB1 and PAR1 variants in Native American, African, European and Brazilian populations. BMC Res Notes. 2016;9(1) [cited 2019 Feb 21] Available from: http://www.biomedcentral.com/1756-0500/9/101.

8. Benedet AL, Moraes CF, Camargos EF, Oliveira LF, Souza VC, Lins TC, et al. Amerindian genetic ancestry protects against Alzheimer's disease. Dement Geriatr Cogn Disord. 2012;33(5):311-7.

9. Brum DG, Luizon MR, Santos AC, Lana-Peixoto MA, Rocha CF, Brito ML, et al. European ancestry predominates in neuromyelitis optica and multiple sclerosis patients from Brazil. PLoS One. 2013;8(3):e58925.

10. Rolim H, Cronemberger S, Rangel H, Batista WD, Bastos-Rodrigues L, De Marco $L$. The role of genetic ancestry in Brazilian patients with primary congenital Glaucoma. J Glaucoma. 2016;25(1):e24-8.

11. Souza MCLA, Martins CS, Silva-Junior IM, Chriguer RS, Bueno AC, Antonini SR, et al. NR3C1 polymorphisms in Brazilians of Caucasian, African, and Asian ancestry: glucocorticoid sensitivity and genotype association. Arq Bras Endocrinol Metabol. 2014:58(1):53-61.

12. da Silva EM, Fernandes MR, de Carvalho DC, Leitao LPC, Cavalcante GC, Pereira EEB, et al. Effect of genetic ancestry to the risk of susceptibility to gastric cancer in a mixed population of the Brazilian Amazon. BMC Research Notes. 2017;10(1) [cited 2019 Feb 21] Available from: https://bmcresnotes. biomedcentral.com/articles/10.1186/s13104-017-2963-4.

13. INCA. INCA - Instituto Nacional de Câncer - Estimativa. 2018. INCA Instituto Nacional de Câncer. 2018 [cited 2019 Feb 9]. Available from: http:// www1.inca.gov.br/estimativa/2018/.

14. Sambrook J, Fritsch EF, Maniatis T. Molecular cloning: a laboratory manual. Molecular cloning: a laboratory manual. 1989 [cited 2019 Apr 5];(Ed. 2). Available from: https://www.cabdirect.org/cabdirect/abstract/19901616061.

15. Santos NPC, Ribeiro-Rodrigues EM, Ribeiro-dos-Santos ÂKC, Pereira R, Gusmão L, Amorim A, et al. Assessing individual interethnic admixture and population substructure using a 48-insertion-deletion (INSEL) ancestryinformative marker (AIM) panel. Hum Mutat. 2010;31(2):184-90.

16. Andrade RB, Amador MAT, Cavalcante GC, Leitão LPC, Fernandes MR, Modesto AAC, et al. Estimating Asian Contribution to the Brazilian Population: A New Application of a Validated Set of 61 Ancestry Informative Markers. G3\&amp;\#58; Genes|Genomes|Genetics. 2018;8(11):3577-82. 
17. Pritchard JK, Stephens M, Donnelly P. Inference of population structure using multilocus genotype data. Genetics. 2000;155(2):945-59.

18. R Core Team. R: a language and environment for statistical computing. $R$ Foundation for statistical Computing; 2014. Available from: http://www.Rproject.org/.

19. Team JASP. JASP (Version 0.9); 2018

20. Hanahan D, Weinberg RA. Hallmarks of cancer: the next generation. Cell. 2011 Mar 4;144(5):646-74.

21. 1000 Genomes Project Consortium, Auton A, Brooks LD, Durbin RM, Garrison EP, Kang HM, et al. A global reference for human genetic variation. Nature. 2015;526(7571):68-74.

22. Cavalcante GC, Amador MA, Ribeiro Dos Santos AM, Carvalho DC, Andrade $\mathrm{RB}$, Pereira EE, et al. Analysis of 12 variants in the development of gastric and colorectal cancers. World J Gastroenterol. 2017;23(48):8533-43.

23. Yu K-D, Di G-H, Fan L, Shao Z-M. Test of hardy-Weinberg equilibrium in breast cancer case-control studies: an issue may influence the conclusions. Breast Cancer Res Treat. 2009;117(3):675-7.

24. Tourneur L, Chiocchia G. FADD: a regulator of life and death. Trends Immunol. 2010;31(7):260-9.

25. Mayr C. What are 3' UTRs doing? Cold spring Harb Perspect biol; 2018

26. Tourneur L, Buzyn A, Chiocchia G. FADD adaptor in cancer. Med Immunol. 2005:4:1.

27. Carvalho DC, Wanderley AV, Amador MAT, Fernandes MR, Cavalcante GC, Pantoja KBCC, et al. Amerindian genetic ancestry and INDEL polymorphisms associated with susceptibility of childhood B-cell leukemia in an admixed population from the Brazilian Amazon. Leuk Res. 2015;39(11):1239-45.

\section{Publisher's Note}

Springer Nature remains neutral with regard to jurisdictional claims in published maps and institutional affiliations.

Ready to submit your research? Choose BMC and benefit from:

- fast, convenient online submission

- thorough peer review by experienced researchers in your field

- rapid publication on acceptance

- support for research data, including large and complex data types

- gold Open Access which fosters wider collaboration and increased citations

- maximum visibility for your research: over $100 \mathrm{M}$ website views per year

At $\mathrm{BMC}$, research is always in progress.

Learn more biomedcentral.com/submissions 